\title{
小児期に於ける各種無機成分の代謝に関する研究
}

\section{On the Metabolism of the Mineral Elements in Infantile Period}

第 2 報 乳児の血清中の無機成分とその栄養状態

2. The Mineral Contents of the Infantile Serum and its Nutritional Condition

(昭和 31 年 2 月 24 日受理)

後 藤 $た$
(Tre Goto)

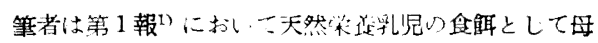

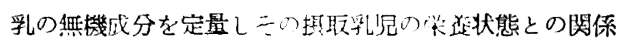
を見出したが今回はそれ等天然采促乳男い血清中の無機 成分を定量してその栄透状態との閣係並びに第 1 報の母 乳成分との関連性を検討し, 更に又参考としてそれ等の 母乳分泌者の血清中の無機成分をも定量してその間の消 長をも研究したのでここに報告する。

\section{実 験 の 部}

（1）被駼者

被験者は第 1 報において報告した被験者の中からその 一部を無作意に抽出した。更に又乳汁分泌者も上記被験 者の母に限つた。

（2）血清の採取

血清は出来るだけ空腹時に採取する目的で目乳給与時 間の 1 時間前から直前迄に相当する午前 10 時か.ら正午 迄の血清を採取した。同样の理により母孚分泌者の血清 も昼食前のを採取した。

(3) 試粼の処理法

\section{表 1 表 栄䓹良好及び栄着不良乳児の血清中の無機} 成分含量 $(\mathrm{mg} / \mathrm{dl})$

\begin{tabular}{|c|c|c|c|c|c|c|c|c|}
\hline \multirow{2}{*}{ 血清の分類 } & \multirow{2}{*}{ 人名 } & \multicolumn{2}{|c|}{$\mathrm{Ca}$} & \multirow{2}{*}{ P } & \multirow{2}{*}{$\mathrm{Na}$} & \multirow[b]{2}{*}{$\mathrm{K}$} & \multirow{2}{*}{$\mathrm{Fe}$} & \multirow{2}{*}{$\mathrm{Cu}$} \\
\hline & & $\stackrel{\mathrm{Ca}}{\mathrm{Catil}}$ & $\stackrel{++}{\mathrm{Ca}^{+}}$ & & & & & \\
\hline \multirow{10}{*}{$\begin{array}{l}\text { 栄楸良好 } \\
\text { 乳罗の血 } \\
\text { 清 }\end{array}$} & a $3(2)$ & 8.5 & 2.8 & 4.6 & 285 & 34 & 0.10 & 0.09 \\
\hline & b $\delta(3)$ & 9.4 & 4.1 & 4.4 & 265 & 24 & 0.09 & 0.06 \\
\hline & $c \&(3)$ & 8.9 & 4.1 & - & 280 & 27 & - & - \\
\hline & $\mathrm{d} \delta(9)$ & 8.9 & 3.8 & 4.3 & 313 & 37 & 0.10 & 0.06 \\
\hline & $\mathrm{e}+(2)$ & 9.0 & 5.1 & 5.6 & 310 & 28 & 0.11 & 0.10 \\
\hline & $f \quad q(4)$ & 11.3 & 6.1 & - & 275 & 30 & - & - \\
\hline & $g$ o $(6)$ & 7.3 & 2.2 & 4.4 & 235 & 25 & - & - \\
\hline & $\mathrm{h}+(2)$ & 8.2 & 3.4 & 4.9 & 305 & 29 & 0.05 & 0.06 \\
\hline & i $\hat{\delta}(8)$ & 10.1 & 3.4 & 5.1 & 255 & 29 & - & - \\
\hline & 平 均 & (9.1) & (3.9) & (4.7) & $(280)$ & (29 & $(0.09)$ & $(0.09)$ \\
\hline
\end{tabular}

第 1 表つづ る

\begin{tabular}{|c|c|c|c|c|c|c|c|c|}
\hline 血清の分類 & 人名 & $\begin{array}{c}\mathrm{Cuti:1} \\
\mathrm{Ca}\end{array}$ & $\mathrm{Ca}_{++}^{+}$ & $P$ & $\mathrm{Na}$ & $\mathbf{K}$ & $\mathrm{Fe}$ & $\mathrm{Cu}$ \\
\hline \multirow{5}{*}{$\begin{array}{l}\text { 栄着不良 } \\
\text { 乳児の血 } \\
\text { 洴 }\end{array}$} & a $\delta(6)$ & 9.1 & 4.7 & 4.7 & 278 & 15 & 0.06 & 0.09 \\
\hline & b $\delta(4)$ & 8.8 & 1.7 & 5.1 & 260 & 31 & 0.12 & 0.06 \\
\hline & c $+(5)$ & 8.6 & 2.8 & 4.3 & 255 & 28 & 0.06 & 0.06 \\
\hline & $\mathrm{d} P(7)$ & 9.6 & 4.6 & 4.3 & 290 & 21 & - & - \\
\hline & 平 均 & & 12,1 & & & & & \\
\hline
\end{tabular}

第 2 表 母乳分泌者の血清中の無機成分含量 $\mathrm{mg} / \mathrm{dl}$

\begin{tabular}{|c|c|c|c|c|c|c|c|c|c|}
\hline \multirow[b]{2}{*}{ 血清の分類 } & \multirow[b]{2}{*}{ 人 } & \multicolumn{3}{|c|}{$\mathrm{Ca}$} & \multirow[b]{2}{*}{$\mathbf{P}$} & \multirow[b]{2}{*}{$\mathrm{Na}$} & \multirow[b]{2}{*}{$\mathrm{K}$} & \multirow[b]{2}{*}{$\mathrm{Fe}$} & \multirow[b]{2}{*}{$\mathrm{Cu}$} \\
\hline & & 名 & ${ }_{\mathrm{Ca}}^{\mathrm{cota1}}$ & $\stackrel{++}{\mathrm{Ca}^{++}}$ & & & & & \\
\hline \multirow{7}{*}{ 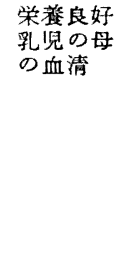 } & a & & 10.3 & 3.2 & 3.5 & 288 & 30 & 0.05 & 0.09 \\
\hline & b & & 9.4 & 3.1 & 4.9 & 295 & 22 & - & - \\
\hline & c & & 10.2 & 4.3 & 4.6 & 275 & 35 & 0.11 & 0.09 \\
\hline & d & & 9.0 & 3.8 & 4.0 & 295 & 28 & 0.11 & 0.12 \\
\hline & e & & 9.2 & 4.4 & 3.5 & 280 & 28 & 0.09 & 0.15 \\
\hline & $\mathrm{f}$ & & 9.7 & 4.5 & 3.9 & 320 & 29 & 0.11 & 0.06 \\
\hline & 平 & 均 & (9.6) & (3.9) & $(4.0)$ & (292) & (28) & $(0.09)($ & $(0.10)$ \\
\hline \multirow{3}{*}{$\begin{array}{l}\text { 栄荞不良 } \\
\text { 虬児の母 } \\
\text { の血清 }\end{array}$} & a & & 8.4 & 3.7 & 4.3 & 270 & 27 & 0.06 & 0.09 \\
\hline & b & & 10.0 & 3.9 & 3.4 & 280 & 29 & 0.05 & 0.18 \\
\hline & 平 & 均 & (9.2) & (3.8) & 13.9 & (275) & (28) & $(0.06)$ & $(0.14)$ \\
\hline
\end{tabular}

探取血清は直ちに冷藏㞄搬して total $\mathrm{Ca}, \mathrm{Ca}_{2}{ }^{++} \mathrm{P}$. $\mathrm{Na}, \mathrm{K}$. の定量に際してはそのまま一部を探り $\mathrm{Fe} . \mathrm{Cu}$ は血清そのbのを再蒸溜硝酸 (1:2) 1ccにて溶かして 蒸発皿に移し, 容器を更に洗つて洗液を加えて乾固し再 び再蒸溜硝酸 (1:1) $5 \mathrm{cc}$ にて溶かしこれを水で以て $25 \mathrm{cc}$ となし偲過しその一部を試料となした。

（4）定量法 $\mathrm{Ca}, \mathrm{P}, \mathrm{Na}, \mathrm{K}, \mathrm{Fe}, \mathrm{Cu}$ の定量法は第 1 報 に報告したと同じ方法によつた。 


\section{実 験 成 績}

実験の結果は第 1 表および第 2 表に絵括し，更に第 1 報に報告した母乳成分との関保を第 3 表に示した。

第3表 母乳の無成分含量とその分泌者の血清並びに その振取知児の血清中の無機成分含量について ( $\mathrm{mg} / \mathrm{dl}$ )

\begin{tabular}{|c|c|c|c|c|c|c|c|c|}
\hline \multirow{2}{*}{ 試 } & 孚児 & \multicolumn{2}{|c|}{$\mathrm{Ca}$} & \multirow[b]{2}{*}{$\mathbf{P}$} & \multirow{2}{*}{$\mathrm{Na}$} & \multirow[b]{2}{*}{$\mathrm{K}$} & \multirow[b]{2}{*}{$\mathrm{Fe}$} & \multirow[b]{2}{*}{$\mathrm{Cu}$} \\
\hline & 栄港状悲 & Ca & $\stackrel{++}{\mathrm{Ca}^{+}}$ & & & & & \\
\hline \multirow[t]{2}{*}{ 母孚 } & 栄養良好 & 45.2 & 11.2 & 12.2 & 20.7 & 79.3 & 0.22 & 0.046 \\
\hline & 栄養不良 & 24.2 & 7.3 & 8.3 & 29.0 & 78.9 & 0.20 & 0.041 \\
\hline \multirow{2}{*}{$\begin{array}{l}\text { 母乳分泌 } \\
\text { 者の血清 }\end{array}$} & 栄養良好 & 9.6 & 3.9 & 4.0 & 292 & 28.0 & 0.09 & 0.10 \\
\hline & 栄養不良 & 9.2 & 3.8 & 3.9 & 275 & 28.0 & 0.06 & 0.14 \\
\hline \multirow{2}{*}{ 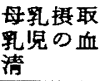 } & 栄養良好 & 9.1 & 3.9 & 4.7 & 280 & 29.0 & 0.09 & 0.09 \\
\hline & 栄養不良 & 9.0 & 3.6 & 4.6 & 271 & 24.0 & 0.08 & 0.07 \\
\hline
\end{tabular}

以上の結果を要約すれば次の如し

(1) 乳児の血清の無譏成分は月令および性別による差 異は特に認められない，又、相当個人差が多い上5であ る。

(2) 栄意良好乳児の血清中の total Ca は最大 11.3 最小 7.3 の間にあつて栄䉵不良乳児の血消も大体その間 の含有量を示し，その他の無呼成分 $\mathrm{Ca}^{++}, \mathrm{P}, \mathrm{Na}, \mathrm{K}$, $\mathrm{Fe}, \mathrm{Cu}$ などについても栄食良好児と不良児との間に特

\section{第 2 号}

別の差異は珰められなかつた。

(3) 母親の血消中の無機成分もその分泌乳汁の成分と の間に特に関連性を見受けなかつた。乳汁の無機成分は 第 1 報1)に報告した如く栄整良好乳児の掑取母乳の total Ca 及び $\mathrm{Ca}^{++}, \mathrm{P}$ 等は含量多く $\mathrm{Na}$ は反対に少 ない傾向にあつたが，母親の血清中の total $\mathrm{Ca}$ 及び $\mathrm{Ca}^{++}, \mathrm{P}, \mathrm{Na}$ 等には上述の母乳に見るよ5な差異は見 出されなかつた。

\section{考察及び総括}

以上を総括すれば孚览及び母親の血洞の無機成分は相

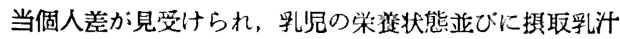
の成分とはその間に特別の関係は見出されなかつた。

斎藤氏は人工栄荃乳児の血清中の $\mathrm{Ca}$ はその掑取牛乳 の $\mathrm{Ca}$ か汘乳より多いにもかかわらず決して母乳児より 多くないと報告”)しているが，今回の央験成績からみて

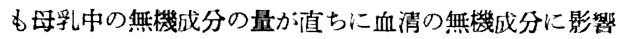
を及ぼすものとは考えられない。

$$
\text { 文献 }
$$

1) 後藤た一：第 1 報，乳児の食铒 (人乳) 中の無 成分と栄意状態 栄湌と食糃誌儿投稿中

2）余藤交雄：栄䄳と食糧 Vol. 2, No. 2, p 4. (1949) (東北大医学部小贤科)

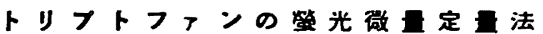

トリブトファンと葡萄榶との反心によつて生ずる罃光 を定量に応用する方法である。なお天然物試料ではトリ ブトファン以外の各喠アミノ酸か:定量に当つて邪應にな るのでイオン交換樹脂を用いて分羅した試料湤を用い る。

蛋白加水分解物をDowex-50 のイオン交換樹脂に通 し，トリプトフォンのみを pH. 6.8 の磷酸緩鲉液を用い て溶出する。この溶出液の $\mathrm{pH}$ を 1.38 に調整し, 又ト リブトファン含量を試料一定量 $(5 \mathrm{ml})$ 中 $20 \gamma$ 以下と する。この試料液に $5 \mathrm{ml}$ のクェン酸ソーダ-塩酸緩衡
液 (pH. 1.38) を添加する，この綏衡液 $5 \mathrm{ml}$. 中にダル コース $0.8 \mathrm{~g}$ を含むよ5に調整しておく，この反心派を $118 \mathrm{C} に 4$ 時間加熱し冷却する，この反応液 $2 \mathrm{ml}$ をク エン酸ソーダ-塩酸䋾衡液 ( $\mathrm{pH} .1 .8$ ) で $25 \mathrm{ml}$ に5寸め,

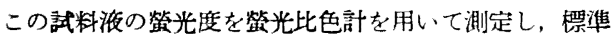
曲線よりトリブトファン量を求めた。

Fluorometric micromethod for determination of tryptophan. by G. D. Mieler and J. A. Johnson. Anal. Chcm., 28, 884 887 (1956)

（福 場） 